JPdK Volume 2 No 2 Tahun 2020 Halaman 179-182 JURNAL PENDIDIKAN dan KONSELING

Research \& Learning in Primary Education

\title{
Peningkatan Kemampuan Berpikir Kritis Dengan Menggunakan Model Problem Based Learning (PBL) Pada Siswa Kelas IV MI Al-Falah
}

\author{
Nurul Aini' ${ }^{1}$, Yenni Fitra Surya ${ }^{2}$, Putri Hana Pebriana ${ }^{3}$ \\ Program Studi Pendidikan Guru Sekolah Dasar \\ Fakultas Ilmu Pendidikan \\ Universitas Pahlawan Tuanku Tambusai \\ Email:nurulainii065@gmail.com
}

\begin{abstract}
Abstrak
Penelitian ini di latarbelakangi oleh rendahnya kemampuan berpikir kritis siswa pada pembelajaran IPA di kelas IV MI Al-Falah Teratak. Salah satu solusi untuk mengatasi masalah ini adalah dengan menggunakan model problem based learning (PBL). Penelitian ini bertujuan untuk mengetahui peningkatan kemampuan berpikir kritis siswa dengan menggunakan model problem based learning (PBL) pada siswa kelas IV MI Al-Falah Teratak. Metode penelitian ini adalah Penelitian Tindakan Kelas (PTK) yang dilaksanakan dalam dua siklus.Setiap siklus terdiri dari dua pertemuan dan empat tahap, yaitu perencanaan, pelaksanaan, observasi, refleksi, dan waktu penelitian dilaksanakan pada bulan September jumlah laki-laki 4 orang, dan siswa perempuan berjumlah 6 orang siswa. Teknik pengumpulan berupa dokumentasi, observasi, dan tes. Pada siklus I hasil kemampuan berpikir kritis siswa tergolong kurang dengan persentase 50\%. Selanjutnya pada siklus II dengan persentase $90 \%$ dengan kategori sangat baik. Dari 10 orang siswa hanya 9 orang siswa yang tuntas dengan ketuntasan klasikal $80 \%$. Dengan demikian dapat disimpulkan bahwa dengan menggunakan model problem based learning (PBL)dapat meningkatkan kemampuan berpikir kritis siswa kelas IV MI Al-Falah Teratak Tahun ajaran 2020/2021.
\end{abstract}

Kata Kunci : Kemampuan berpikir kritis, model problem based learning $(P B L)$

Abstract

This research was motivated by the low critical thinking skills of students in science learning in class IV MI Al-Falah Teratak. One solution to overcome this problem is to use a problem based learning (PBL) model. This study aims to determine the improvement of students' critical thinking skills by using the problem based learning (PBL) model in grade IV students at MI Al-Falah Teratak. This research method is Classroom Action Research (PTK) which is carried out in two cycles. Each cycle consists of two meetings and four stages, namely planning, implementing, observing, reflecting, and when the research was carried out in September the number of boys was 4 people, and female students were 6 students. Collection techniques in the form of documentation, observation, and tests. The results of this study concluded that the problem based learning (PBL) model can improve students' critical thinking skills in class IV MI Al-Falah Teratak. In the first cycle the results of students' critical thinking skills were classified as less with a percentage of $50 \%$. Furthermore, in cycle II with a percentage of $90 \%$ in the very good category. Of the 10 students, only 9 students completed with $80 \%$ classical completeness. Thus it can be concluded that using the problem based learning (PBL) model can improve the critical thinking skills of grade IV students at MI Al-Falah Teratak for the 2020/2021 school year.

Keywords: Improvement, critical thinking skills, problem based learning (PBL) model 


\section{PENDAHULUAN}

Ilmu Pengetahuan Alam (IPA) merupakan ilmu yang pada awalnya diperoleh dan dikembangkan berdasarkan percobaan (induktif) namun pada perkembangan selanjutnya Ilmu Pengetahuan Alam (IPA) juga diperoleh dan dikembangkan berdasarkan teori (deduktif). Ada dua hal berkaitan yang tidak terpisahkan dengan Ilmu Pengetahuan Alam (IPA) yaitu Ilmu Pengetahuan Alam (IPA) sebagai produk, Ilmu Pengetahuan Alam (IPA) yang berupa pengetahuan faktual, konseptual, prosedural, dan metakognitif, dan Ilmu Pengetahuan Alam (IPA) sebagai proses yaitu kerja ilmiah. Menurut Wisudawati (2014: 22) Saat ini objek kajian Ilmu Pengetahuan Alam (IPA) menjadi semakin luas, meliputi konsep Ilmu Pengetahuan Alam (IPA), proses, nilai, dan sikap ilmiah, aplikasi Ilmu Pengetahuan Alam (IPA) dalam kehidupan sehari-hari, dan kreativitas sedangkan menurut Sukarno (2015: 23) Ilmu Pengetahuan Alam (IPA) dapat diartikan sebagai ilmu yang mempelajari tentang sebab dan akibat kejadian-kejadian yang ada di alam ini.

Standar kelulusan satuan pendidikan (SKL-SP) mata pelajaran Ilmu Pengetahuan Alam (IPA) di tingkat sekolah dasar adalah anak mampu berpikir logis, kritis, dan kreatif tentang lingkungan sekitarnya. Ketiga hal tersebut dapat tercapai jika dalam proses pembelajaran, guru berperan sebagai fasilitator dan motivator bagi siswa. Dengan memberikan kesempatan kepada siswa untuk belajar secara mandiri. Salah satu kemampuan yang perlu dikembangkan untuk mencapai keterampilan abad 21 adalah kemampuan berpikir kritis dalam menyelesaikan atau memecahkan masalah. Kemampuan berpikir kritis perlu dikembangkan kepada setiap siswa. Pentingnya kemampuan berpikir kritis bagi setiap siswa yaitu agar siswa dapat memecahkan segala permasalahan yang ada di dalam dunia nyata.

Menurut Lilis (2019: 8) berpikir kritis adalah sebuah proses intelektual dengan melakukan pembuatan konsep, penerapan, melakukan sintesis dan mengevaluasi informasi yang diperoleh dari observasi, pengalaman, refleksi, pemikiran, atau komunikasi sebagai dasar untuk meyakini dan melakukan suatu tindakan. Menurut Ennis (dalam Linda, 2019: 3) Berpikir kritis adalah suatu proses berpikir reflektif yang berfokus pada memutuskan apa yang diyakini atau dilakukan. Sedangkan menurut Elaine (2007: 183) Berpikir kritis merupakan sebuah proses yang terarah dan jelas yang digunakan dalam kegiatan mental seperti memecahkan masalah, mengambil keputusan, membujuk, menganalisis asumsi, dan melakukan penelitian ilmiah. Sejalan di era pesatnya perkembangan iptek, kemampuan berpikir kritis semakin dipandang perlu, setiap waktu kita dituntut untuk berpikir kritis, tidak menerima sesuatu hanya begitu saja, harus mencari sebab dan bukti-bukti yang mendukung dari data-data yang kita terima. Kemampuan berpikir kritis juga sudah seharusnya dimasukan kedalam kurikulum sekolah, sudah seharusnya peserta didik dari pendidikan dasar diajarkan mengenai berpikir kritis. Dengan berpikir kritis siswa akan semakin cerdas karena proses interaksi yang berlangsung, mereka berdiskusi dan berdebat tentang apa yang diyakininya benar. Berpikir kritis telah menjadi salah satu kompetensi dari tujuan pendidikan dan sebagai alat dalam mengkonstruksikan pengetahuan, selama menempuh pendidikan, berpikir kritis dapat membantu siswa dalam meningkatkan pemahaman materi yang dipelajari dengan mengevaluasi secara kritis argumen pada buku teks, jurnal, teman diskusi, termasuk argumen guru dalam kegiatan pembelajaran. Dalam meningkatkan mutu pendidikan pemerintah selalu berupaya untuk melakukan segala bentuk perubahan di antaranya sistem pendidikan dan kurikulum.

Guru belum maksimal dalam menggunakan model pembelajaran yang melatih kemampuan kognitif siswa aspek tingkat tinggi seperti analisis mengolah masalah, mengevaluasi, dan menciptakan. Akibatnya siswa juga belum terbiasa menyelesaikan suatu permasalahan yang didahului dengan kegiatan penyelidikan. Hal tersebut yang membuat tingkat kemampuan berpikir kritis siswa lemah, sehingga berdampak pada hasil belajarnya yang rendah dan kurang berkembangnya kemampuan berpikir kritis pada siswa.

Salah satu model pembelajaran yang dapat dikembangkan dan diadopsi untuk menempatkan siswa sebagai pusat pembelajaran adalah penerapan model Problem Based Learning (PBL). Model Problem Based Learning (PBL) merupakan pembelajaran yang menantang peserta didik untuk belajar bagaimana belajar dan bekerja secara berkelompok untuk mencari solusi dari permasalahan dunia nyata. Masalah yang diberikan ini digunakan untuk mengikat rasa ingin tahu siswa tentang pembelajaran yang dimaksud. Masalah diberikan kepada siswa mempelajari konsep atau materi yang berkenaan dengan masalah yang harus dipecahkan (Surya, 2017).

Berdasarkan uraian tersebut, dapat disimpulkan bahwa model Problem Based Learning (PBL) merupakan model pembelajaran yang melibatkan siswa dalam memecahkan masalah nyata dengan cara bekerjasama dalam kelompok untuk mencari solusi, dan membangun pengalaman baru. 
Model Problem Based Learning (PBL) ini dapat meningkatkan kemampuan berpikir kritis pada siswa dan rasa ingin tahu siswa. Model Problem Based Learning (PBL) juga menjadi wadah bagi siswa untuk dapat mengembangkan cara berpikir kritis dan kemampuan berpikir kritis yang lebih tinggi. Berdasarkan latar belakang seperti yang dikemukakan diatas, peneliti tertarik untuk melakukan penelitian ini dengan judul "Peningkatan Kemampuan Berpikir Kritis dengan Menggunakan Model Problem Based Learning (PBL) pada Siswa Kelas IV di MI Al-Falah Teratak".

\section{METODOLOGI PENELITIAN}

Metode yang digunakan dalam penelitian ini adalah metode Penelitian Tindakan Kelas (PTK). Penelitian Tindakan Kelas (PTK) adalah penelitian yang dilakukan oleh guru di kelasnya sendiri dengan cara merencanakan, melaksanakan,dan merefleksikan tindakan secara kolaboratif dan partisifatif dengan tujuan memperbaiki kinerjanya sebagai guru, sehingga kemampuan berpikir kritis meningkat (Pebriana, 2018).

Menurut Car dan Kemmis (dalam Citra, 2019) Penelitian Tindakan Kelas (PTK) adalah suatu bentuk penelitian refleksi diri yang dilakukan oleh para partisipan dalam situasi social untuk memperbaiki rasionalitas dan kebenaran. Penelitian tindakan kelas merupakan suatu pencermatan terhadap kegiatan belajar berupa sebuah tindakan yang sengaja dimunculkan dan terjadi dalam sebuah kelas secara bersama (Arianto, dalam Citra, 2019). Berdasarkan definisi diatas maka dapat disimpulkan bahwa Penelitian Tindakan Kelas (PTK) adalah keaktifan siswa, karena dalam pembelajaran siswa yang diutamakan. Penelitian tindakan kelas (PTK) mempunyai karakteristik yang khas, yaitu guru menjadi pelaksana dalam kegiatan penelitian, berasal dari permasalahan praktik pembelajaran yang faktual, dan adanya tindakan-tindakan tertentu untuk memperbaiki proses belajar mengajar yang dilaksanakan dalam ruang kelas dengan tahapan-tahapan tindakan tertentu dengan tujuan memperbaiki pembelajaran.

\section{HASIL PENELITIAN DAN PEMBAHASAN}

Berdasarkan hasil penelitian yang sudah didapatkan, maka ada beberapa hal yang perlu dibahas terkait penelitian ini, yaitu kelebihan dan kelemahan menggunakan model problem based learning (PBL) pada pembelajaran IPA untuk meningkatkan keterampilan berpikir kritis siswa. Model ini terdiri dari 5 langkahlangkah, sebagai berikut :1) Memberikan orientasi terhadap permasalahan, 2) Mengorganisasikan siswa untuk melakukan tugasnya, 3) Membantu siswa melakukan tugasnya tersebut, 4) Mengembangkan hasil diskusi, dan 5) Menganalisis dan mengevaluasi pemecahan masalah.

Pada proses penelitian yang dilakukan oleh peneliti untuk meningkatkan keterampilan berpikir kritis siswa dengan menggunakan

model problem based learning (PBL) ditemukan beberapa kelebihan model problem based learning (PBL) yaitu :

1) Siswa didorong untuk memiliki kemampuan memecahkan masalah dalam situasi nyata, 2) Siswa memiliki kemampuan membangun pengetahuannya sendiri melalui aktivitas belajar, 3) Pembelajaran berfokus pada masalah sehingga materi yang tidak ada hubungannya tidak perlu dipelajari oleh siswa. Hal ini mengurangi beban siswa dengan menghafal atau menyimpan informasi,4) Terjadi aktivitas ilmiah pada siswa melalui kerja kelompok, 5) Siswa terbiasa menggunakan sumber-sumber pengetahuan, baik dari pespustakaan, internet, wawancara, dan observasi, 6) Siswa memiliki kemampuan menilai kemajuan belajarnya sendiri, 7) Siswa memiliki kemampuan untuk melakukan komunikasi ilmiah dalam kegiatan diskusi atau presentasi hasil pekerjaan mereka, dan 8) Kesulitan belajar.

Model problem based learning (PBL) tidak dapat diterapkan untuk setiap materi pelajaran, ada bagian guru berperan aktif dalam menyajikan materi. PBL lebih cocok untuk pembelajaran yang menuntut kemampuan tertentu yang kaitannya dengan pemecahan masalah

Ditinjau pada hasil pratindakan, bahwa tingkat kemampuan berpikir kritis siswa rendah, Dengan jumlah siswa 10 siswa terdapat 2 siswa atau (20\%) yang memperoleh nilai diatas KKM yang diterapkan dan 8 siswa atau (80\%) siswa yang belum mencapai nilai KKM. Dapat disimpulkan bahwa tingkat kemampuan berpikir kritis siswa kelas IV tahun ajaran 2019/2020 tergolong masih rendah dan dapat digolongkan tidak kritis.

Pada siklus I hasil kemampuan berpikir kritis siswa tergolong kurang dengan persentase $50 \%$. Selanjutnya pada siklus II dengan persentase $90 \%$ dengan kataegori sangat baik. Dari 10 orang siswa hanya 9 orang siswa yang tuntas dengan ketuntasan klasikal 80\%. Dengan demikian dapat disimpulkan bahwa dengan menggunakan model problem based learning (PBL) dapat meningkatkan kemampuan berpikir kritis siswa kelas IV MI Al-

FalahTeratak Tahun ajaran 2020/2021. 


\section{SIMPULAN}

Berdasarkan hasil penelitian yang telah dilaksanakan selama dua siklus dengan menggunakan model Problem Based Learning (PBL) untuk peningkatan kemampuan berpikir kritis siswa pada siswa kelas IV MI Al-Falah Teratakpada semester ganjil 2020/2021, dapat ditingkatkan dengan menggunakan model Problem Based Learning (PBL). Peningkatan kemampuan berpikir kritis siswa dapat dilihat dari hasil data observasi yang diperoleh yaitu kemampuan berpikir kritis siswa dalam menyelesaikan masalah sudah kritis. Dan kemampuan berpikir kritis siswa meningkat.

Melalui pembelajaran dengan menggunakan model Problem Based Learning (PBL) siswa lebih mudah untuk mengembangkan kemampuan berpikir kritisnya meningkat.Peningkatan tersebu dapat dilihat dari adanya peningkatan persentase dari tahap pratindakan dan setelah dilakukan tindakan kelas.Hasil observasi pada tahap pratindakan siswa yang kategori cukup hanya 1 siswa dan yang baik 1 siswa. Setelah dilakukan tindakan siklus I dan II jumlah siswa yang sesuai harapan berjumlah 9 siswa meningkat lebih baik lagi dan masuk kategori sangat baik.

Adapun hasil kemampuan berpikir kritis siswa pada kelas IV MI Al-Falah Teratak pada siklus I mencapai ketuntasan klasikal yaitu $50 \%$ dengan 5 orang siswa yang tuntas. Kemudia pada siklus II ketuntasan meningkat menjadi $90 \%$ dengan siswa yang tuntas 9 orang siswa dan jumlah siswa yang tidak tuntas 1 orang. Dari hasil setiap siklus dapat diperoleh kesimpulan bahwa untuk peningkatan kemampuan berpikir kritis siswa pada siswa kelas IV MI Al-Falah Teratak dapat menggunakan model Problem Based Learning (PBL) dalam proses pembelajaran siswa.

\section{DAFTAR PUSTAKA}

Arikunto, S. (2010). Prosedur Penelitian Suatu Pendekatan Praktik. Jakarta : Rineka Cipta.

Citra, S. (2019). Peningkatan Kemampuan Berpikir Kritis Dengan Menggunakan Model Problem Basic Learning (PBL) pada Kelas IV SDN 003 Ganting Kecamatan Salo. Universitas Pahlawan. Skripsi.

Elaine. (2007). Contextual Teaching and Learning. Bandung : MLC.

Hosnan. (2014). Pendekatan Saintifik dan Kontekstual dalam Pembelajaran Abad 21. Bogor : Ghalia Indonesia.

Iskandar. (2011). Metodelogi Penelitian Pendidikan dan Sosial (Kuantitatif dan
Kualitatif). Jakarta : Gaung Persada Pers.

Johnson, E. (2007). Contextual Teaching and Learning. Bandung : Kaifa.

Lilis. (2019). Berpikir Kritis dan PBL. Surabaya : Media Sahabat Cendekia.

Linda. (2019). Berpikir Kritis dalam Konteks Pembelajaran. Bogor : Erzatama Karya Abadi.

Pebriana, Putri Hana. (2018) Penerapan Metode Hypnoteaching Untuk

Menigkatkan Kemampuan

Menulis Puisi Anak Pada Siswa Kelas III SDN 030 Bagan Jaya. Jurnal Basicedu Vol (2) 1, 148-153.

Sanjaya, W. (2013). Strategi PembelajaranBerorientasi Standar Proses Pendidikan. Jakarta : Kencana.

Shoimin. (2016). 68 Model Pembelajaran Inovatif dalam Kurikulum 2013. Yogyakarta : Ar-Ruzz Media.

Sukarno. (2015). Metodologi Pembelajaran IPA . Jakarta: Bumi Aksara.

Trianto. (2009). Mendesain Model Pembelajaran Inovatif-

Progresif. Jakarta : Kencana Prenada Media Group.

Surya, Yenni Fitra (2017). Peningkatan Kemampuan Berpikir Kritis dan Penguasaan Konsep IPA Siswa SD dengan Menggunakan Model Problem Based Learning. Institut Universitas Pahlawan.

Widiasworo. (2018). Strategi Pembelajaran Edu Tainment Berbasis Karakter. Yogyakarta : Ar-Ruzz Media.

Wijaya. (2012). Metode Penelitian Tindakan Kelas. Jakarta : PT Macanan Jaya Cemerlang.

Wisudawati dan Sulistyowati. (2004). Metodologi Pembelajaran IPA. Jakarta : Bumi Aksara.

Wowo. (2012). Peningkatan Hasil Belajar \begin{tabular}{lcc} 
Siswa & \multicolumn{2}{c}{ dalam } \\
Pembelajaran Matematika dengan \\
menggunakan Problem & Based \\
Learning pada kelas V SDN 1 \\
Tempursari \\
2011/201(DoctoralDissertation).
\end{tabular} UniversitasMuhammadiah Surakarta: Skripsi 